\title{
NOTE
}

\section{Aquatic invertebrates (snails) as new paratenic hosts of Anguillicola crassus (Nematoda: Dracunculoidea) and the role of paratenic hosts in the life cycle of this parasite}

\author{
F. Moravec* \\ Institute of Parasitology, Academy of Sciences of the Czech Republic, Branišovská 31, CZ-370 05 České Budèjovice, Czech Republic
}

ABSTRACT: Aquatic snails Galba corvus (Gmelin) were found to be suitable paratenic hosts for third-stage larvae $\left(\mathrm{L}_{3}\right)$ of the nematode Anguillicola crassus Kuwahara, Niimi et Itagaki, 1974, a pathogenic swimbladder parasite of the eel Anguilla anguilla (L.), which is found in Europe and elsewhere. This is the first evidence that not only prey fishes but also invertebrates can serve as paratenic hosts to this parasite. A. crassus $\mathrm{L}_{3}$ were found unencapsulated, mostly in the tissue of the snail's foot or its haepatopancreas, where they survived for nearly 2 mo. Experimental infections of perch Perca fluviatilis L. with $A$. crassus $\mathrm{L}_{3}$ from copepods confirmed further development of this nematode up to the fourth larval stage, showing that perch belongs to the category of metaparatenic hosts of A. crassus.

KEY WORDS: Parasitic nematode - Anguillicola crassus Paratenic hosts · Aquatic snails - Galba corvus

The nematode Anguillicola crassus Kuwahara, Niimi et Itagaki, 1974, a pathogenic swimbladder parasite of eels, was introduced from East Asia into Europe in the 1980s. It quickly spread to many European and North African countries, sometimes representing a serious problem for the culture of the European eel Anguilla anguilla, as well as to wild eel populations (van Banning \& Haenen 1990, Molnár et al. 1991, Moravec 1992, Baruš 1995). In 1994, this pathogenic parasite was also introduced into North America, infecting the American eel Anguilla rostrata (LeSueur), both in aquaculture and in the wild (Johnson et al. 1995).

Many species of copepods and ostracods have been reported to serve as intermediate hosts to Anguillicola crassus (e.g. Hirose et al. 1976, De Charleroy et al. 1990, Petter et al. 1990, Moravec et al. 1993, Moravec \& Konecny 1994) in which the nematode larvae reach the third stage, the stage that is infective to the defini-

•E-mail: moravec@paru.cas.cz tive host (eel). However, in addition to infected intermediate hosts (e.g. copepods) a further source of infection for eels may be various fish which serve as paratenic hosts in which the larvae remain alive and keep their ability to infect the definitive host. Such fish paratenic hosts of $A$. crassus have been found both in experimental conditions (Petter et al. 1989, De Charleroy et al. 1990, Thomas \& Ollevier 1992, Moravec \& Konecny 1994) and in the natural environment (e.g. De Charleroy et al. 1990, Haenen \& van Banning 1990, Thomas \& Ollevier 1992, Székely 1994). The list of such hosts comprises 33 species of fish belonging to 10 families. While most fish species serving as paratenic hosts to the nematode (e.g. all cyprinids or guppies) are classified as so-called euparatenic (astadiogenous) hosts, Perca fluviatilis L., Lepomis gibbosus (L.) and possibly Gasterosteus aculeatus $\mathrm{L}$. can be considered to be metaparatenic (stadiogenous) hosts or even paradefinitive hosts in accordance with the concepts and terminology of Odening (1976) (see Moravec \& Konecny 1994).

The present study explores further the possible role of paratenic hosts in the life cycle of Anguillicola crassus. Since the diet of eels consists mainly of benthic invertebrates such as higher crustaceans, insect larvae and mollusks (Tesch 1977, Baruš \& Oliva 1995), we were specifically interested in determining whether aquatic invertebrates, in addition to fishes, can serve as paratenic hosts of $A$. crassus. We also tried to study the behaviour of $A$. crassus third-stage larvae $\left(\mathrm{L}_{3}\right)$ in Perca fluviatilis, the fish species reported as the metaparatenic host of this nematode in the natural environment.

For these studies, we used 6 species of aquatic snails: Galba corvus (Gmelin) [syn. Stagnicola palustris (Müller)] (67 specimens); Peregra peregra (L.) (29); Lymnaea stagnalis (L.) (6); Planorbarius corneus (L.) 
(24); Bathyomphalus contortus (L.) (12); Segmentina nitida (Müller) (37); the isopod Asellus aquaticus L. (30), the perch Perca fluviatilis (7); and the frog Rana ridibunda Pallas (2). Snails, isopods and frogs were collected from small ponds in the vicinity of Ceské Budejovice, Czech Republic, whereas perch originated from the breeding stock maintained at the Institute of Parasitology in České Budějovice.

Copepods Cyclops strenuus Fischer originating from ponds near Ceské Budějovice were infected with Anguillicola crassus as described by Moravec et al. (1993); nematodes originated from eels collected from the Orlík water reservoir on the Vltava River, Czech Republic. Feeding experiments were carried out in 17 petri dishes (diameter $19 \mathrm{~cm}$ ); each dish contained a few hundred copepods to which approximately 1000 parasite eggs containing viable larvae were added. After $14 \mathrm{~d}$ at laboratory temperature $\left(21\right.$ to $\left.24^{\circ} \mathrm{C}\right)$, several copepods from each dish were examined. Although most of them (about 90\%) harboured 1 to 2 $\mathrm{L}_{3}$ of $A$. crassus, copepod numbers were drastically reduced due to a relatively high mortality during the experiment. No eggs or free second-stage larvae $\left(L_{2}\right)$ of A. crassus were observed on the bottom of petri dishes at that time. On the same day, about 10 snails of different species were added to each dish, where they remained for the next $3 \mathrm{~d}$; isopods were added to 1 dish. Then the snails were washed and transferred to larger aquaria, where they were fed regularly with lettuce (Lactuca sativa L.). The snails were examined microscopically (pressed between 2 flat glasses) on Days 14, 35, 49, 63, 90 and 111 after possible infection (PI), all Asellus aquaticus specimens were examined on Day $111 \mathrm{PI}$.
Of all invertebrates tested, only Galba corvus were found to be infected with $\mathrm{L}_{3}$ of Anguillicola crassus: the highest number (10 of 12 examined; $83 \%$ ) of infected snails (intensity 1 to 4 larvae per snail; mean 2) was found $14 \mathrm{~d} \mathrm{PI}$, whereas infection was recorded in only 2 of $16(13 \%)$ and 2 of $10(20 \%)$ of the snails examined on Days 35 and $49 \mathrm{PI}$, respectively, (intensity 1 larva per snail in both cases). All conspecific snails examined on Days 63 (24 specimens), 90 (20) and 111 (4) PI, as well as all Asellus aquaticus, proved to be free of A. crassus larvae. All nematode larvae were found unencapsulated, moving in the tissue of the snail's foot (Fig. 1A); only 1 larva was located in the hepatopancreas. Larvae were 888 to $1074 \mu \mathrm{m}$ long and 33 to $39 \mu \mathrm{m}$ wide ( $35 \mathrm{~d} \mathrm{PI}$ ) and their morphology and size were identical with those of conspecific $\mathrm{L}_{3}$ from copepods (Moravec et al. 1993)

To determine whether amphibians may also act as paratenic hosts of Anguillicola crassus, infected copepods harbouring $\mathrm{L}_{3}$ were forced by a stomach tube into the digestive tract of 2 small $(2 \mathrm{~cm}$ long) frogs Rana ridibunda (about 10 larvae per host); these were found to be free of $A$. crassus larvae on Day 8 PI.

Seven specimens of small $(6$ to $8 \mathrm{~cm}$ ) perch Perca $\mathrm{flu}$ viatilis were infected by being placed in a barrel (50 1) containing an undetermined number of Cyclops strenuus, to which a month prior to the fully developed Anguillicola crassus eggs had been added. Fish were allowed to feed spontaneously on the, presumably, infected copepods for $2 \mathrm{~d}$ and then they were transferred to an aquarium and fed with tubificids. Perch were examined on Days 7, 30, 35 and 54 PI. Four fishes (examined on Days 7, 30 and $35 \mathrm{PI}$ ) proved to harbour 1 to 2 live A. crassus $\mathrm{L}_{3}$ on the swimbladder surface; the nematodes
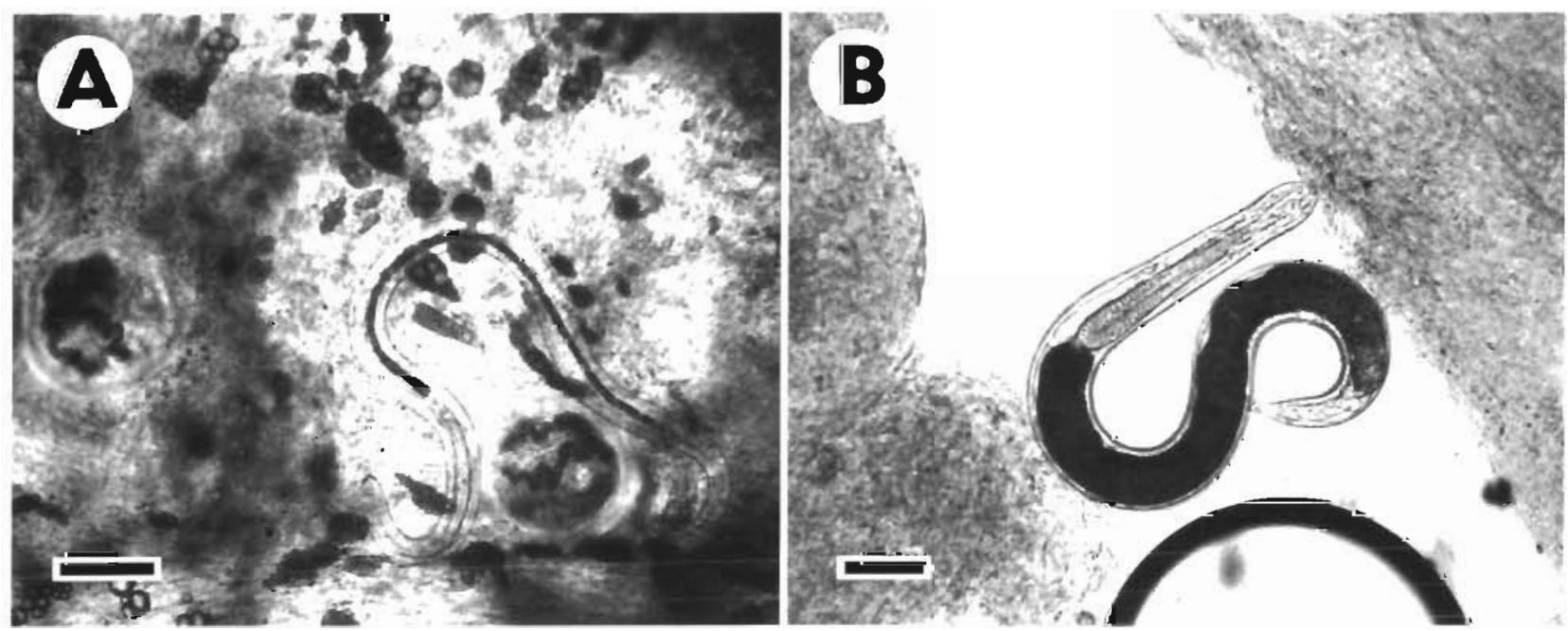

Fig. 1. Anguillicola crassus, Larvae from experimental paratenic hosts (fresh mounts). (A) Third-stage larva in foot tissue of Galba corvus $35 \mathrm{~d}$ after possible infection (PI) (note also 2 spherical cysts of echinostomatid metacercariae). (B) Fourth-stage larva expressed from swimbladder wall of Perca fluviatilis $30 \mathrm{~d}$ PI. Scale bars $=100 \mu \mathrm{m}$ 
were 798 to $952 \mu \mathrm{m}$ long and 34 to $39 \mu \mathrm{m}$ wide and their morphology and size were typical of $\mathrm{L}_{3}$ from copepods.

In addition to $1 \mathrm{~L}_{3}, 1$ infected fish examined on Day 30 PI also harboured a single early fourth-stage larva $\left(\mathrm{L}_{4}\right)$ inside the swimbladder wall (Fig $1 \mathrm{~B}$ ). In contrast to the $\mathrm{L}_{3}$, the body of the $\mathrm{L}_{4}$ was somewhat larger and broader (1290 $\mu \mathrm{m}$ long and $82 \mu \mathrm{m}$ wide), its intestine was broad and brown-coloured, the posterior part of its oesophagus was distinctly expanded, and a developing vulva was present.

The results of this study show, for the first time, that not only various prey fishes but also aquatic invertebrates (snails) may serve as paratenic hosts to Anguillicola crassus, in which nematode infective larvae can survive for nearly 2 mo. Since benthic invertebrates, including snails, form the main portion of eels' food, they might be a significant source of $A$. crassus infection in these fish. We found only a low prevalence of infection in experimental snails; this was probably due to the fact that only very small numbers of infected intermediate host copepods (Cyclops strenuus) survived in petri dishes up to the time when experimental snails were added, and because snails were able to ingest only dying or immobile copepods from the bottom of the vessel and not those still swimming. The fact that, of the snail species tested, only Galba corvus became infected may be associated with the behaviour of this species; in contrast to other snails, G. corvus mostly kept to the bottom of petri dishes.

Aquatic snails have also been recorded as frequent paratenic hosts to other helminths which develop in copepods as intermediate hosts, for example, as hosts to some bird cestodes or for camallanid and other nematodes (Ryšavý 1964, Bartlett \& Anderson 1985). It is highly probable that, in addition to snails, some other benthic invertebrates (e.g. predatory insect larvae) may serve as paratenic hosts of Anguillicola crassus.

It has been demonstrated in this study, for the first time under experimental conditions, that the development of $\mathrm{L}_{3}$ of Anguillicola crassus need not be arrested in perch Perca fluviatilis but that, provided that it penetrates into the wall of the swimbladder, the larva may attain the next (fourth) larval stage after a month. This confirms that some perciform fishes may serve as metaparatenic hosts of $A$. crassus, as was observed by De Charleroy et al. (1990) and Thomas \& Ollevier (1992) in naturally infected $P$. fluviatilis and Lepomis gibbosus in Belgium and that the speed of the development of $A$. crassus from $\mathrm{L}_{3}$ to $\mathrm{L}_{4}$ in these fishes is comparable with that in the definitive host (eel). Further studies on paratenic hosts of $A$. crassus are desirable.

Acknowledgements. I thank Dr Oleg Ditrich and Mrs Irena Husáková of the Institute of Parasitology, ASCR, for the identification of snails and technical assistance, respectively.
This paper was supported by grant no. 508/94/0284 from the Grant Agency of the Czech Republic

\section{LITERATURE CITED}

Bartlett CM, Anderson RC (1985) Larval nematodes (Ascaridida and Spirurida) in the aquatic snail, Lymnaea stagnalis. J Invertebr Pathol 46:153-159

Baruś V (1995) First record of Anguillicola crassus (Nematoda) in the Morava River drainage basin. Helminthologia (Bratisl) 32:89

Baruś V, Oliva O (eds) (1995) Mihulovci Petromyzontes a ryby Osteichthyes, Part 2. Fauna CR a SR 28. Academia, Praha

De Charleroy D, Grisez L, Thomas K, Belpaire C, Ollevier F (1990) The life cycle of Anguillicola crassus. Dis Aquat Org 8:77-84

Haenen OLM, van Banning P (1990) Detection of larvae of Anguillicola crassus (an eel swimbladder nematode) in freshwater fish species. Aquaculture 87:103-109

Hirose H, Sekino T, Egusa S (1976) Notes on egg deposition, larval migration and intermediate host of the nematode Anguillicola crassa parasitic in the swimbladder of eels. Fish Pathol 11:27-31 (in Japanese with English summary)

Johnson SK, Fries LT, Williams J, Huffman DG (1995) Presence of the parasitic swim bladder nematode, Anguillicola crassus, in Texas aquaculture. World Aquaculture 26:35-36

Molnár K, Székely C, Baska F (1991) Mass mortality of eel in Lake Balaton due to Anguillicola crassus infection. Bull Eur Ass Fish Pathol 11:211-212

Moravec F (1992) Spreading of the nematode Anguillicola crassus (Dracunculoidea) among eel populations in Europe. Folia Parasitol 39:247-248

Moravec F, Di Cave D, Orecchia P, Paggi L (1993) Studies on the development of Anguillicola crassus Kuwahara, Niimi et Itagaki, 1974 (Nematoda: Dracunculoidea) in the intermediate host. Folia Parasitol 40:39--48 and Erratum 40:160

Moravec F, Konecny R (1994) Some new data on the intermediate and paratenic hosts of the nematode Anguillicola crassus Kuwahara, Niimi et Itagaki, 1974 (Dracunculoidea), a swimbladder parasite of eels. Folia Parasitol 41:65-70

Odening K (1976) Conception and terminology of hosts in parasitology. In: Dawes $B$ (ed) Advances in parasitology 14. Academic Press, London, p 1-93

Petter A.J, Cassone J, Le Belle N (1990) Observations sur la biologie des premiers stades larvaires d'Anguillicola crassus, nématode parasite d'anguille. Ann Parasitol Hum Comp 65:28-31

Petter AJ, Fontaine YA, Le Belle N (1989) Étude du dévelopment larvaire de Anguillicola crassus (Dracunculoidea) chez un Cyclopidae de la région parisienne. Ann Parasitol Hum Comp 64:347-355

Ryšavý B (1964) The epizootological importance of watersnails in cestodoses of domestic ducks. Ceśk Parasitol 11: $217-223$

Székely Cs (1994) Paratenic hosts for the parasitic nematode Anguillicola crassus in Lake Balaton, Hungary. Dis Aquat Org 18:11-20

Tesch FW (1977) The eel: biology and management of anguillid eels. Chapman \& Hall Ltd., London

Thomas K, Ollevier F (1992) Paratenic hosts of the swimbladder nematode Anguillicola crassus. Dis Aquat Org 13: $165-174$

van Banning P, Haenen OLM (1990) Effects of the swimbladder nematode Anguillicola crassus in wild and farmed eel, Anguilla anguilla. In: Perkins FO, Cheng TC (eds) Pathology in marine science. Academic Press, New York, p 317-330 